\title{
CHANGES OF NATURAL ENVIRONMENT IN KRAKÓW DOWNTOWN - ITS CHRONOLOGY AND DIRECTIONS. CASE GEOARCHAEOLOGICAL STUDIES OF KRUPNICZA STREET SITE
}

\author{
TADEUSZ SOKOLOWSKI ${ }^{1}$, AGNIESZKA WACNIK ${ }^{2}$, MARTA WARDAS ${ }^{1}$, MACIEJ PAWLIKOWSKI $^{1}$, \\ ANNA PAZDUR ${ }^{3}$, JACEK MADEJA ${ }^{4}$, BARBARA WORONKO ${ }^{5}$ and PAWEL MADEJ ${ }^{6}$ \\ ${ }^{I}$ Faculty of Geology, Geophysics and Environmental Protection, Stanisław Staszic AGH University of Science and Technology, \\ Aleja Mickiewicza 30, PL-31-590 Kraków, Poland \\ ${ }^{2}$ Władysław Szafer Institute of Botany, Polish Academy of Sciences, \\ Lubicz 46, PL-31-512 Kraków, Poland \\ ${ }^{3}$ Institute of Physics, The Silesian University of Technology, \\ Krzywoustego 2, PL-44-100 Gliwice, Poland \\ ${ }^{4}$ Institute of Botany, Jagiellonian University, \\ Lubicz 46, PL-31-512 Kraków, Poland \\ ${ }^{5}$ Institute of Physico-Geographical Sciences, Warsaw University, \\ Krakowskie Przedmieście 30, PL-00-950 Warszawa, Poland \\ ${ }^{6}$ Sienkiewicza 14/8, PL-30-033 Kraków, Poland
}

\begin{abstract}
Sediments exposed in a construction excavation form a sequence: alluvial deposits $>$ black soil $>$ made ground. Peat-like deposits, organic muds and occasionally sand occur between the soil and the made ground. High aeolization of alluvial sediments allows relating their age to the Late Vistulian. The sediments were eroded and in the washout at first organic muds were deposited and subsequently sands. The lowest layer, radiocarbon-dated at $4510 \pm 60$ uncal. years BP (Gd-12724), can be probably linked to climate moistening at the transition between the Holocene Atlantic and the Subboreal period. Pollen grains found in muds, black soil and peat-like deposits reflect the changes of local plant cover from dominated by pine woodlands (at the transition between the Atlantic and the Subboreal period) to strongly deforested with single trees, meadows, small crop fields and gardens in the Medieval period. Palynological results describing the character of vegetation might have been influenced also by direct human activity on site, e.g. by storage of wood and branches (then used as construction material or fuel), crops, fodder or waste. Microartefacts found in soil suggest metal processing in the vicinity during the Bronze Age. In the made ground, which has been accumulating since the 14th century, quartz, clay minerals and micas were identified together with fragments of bricks, concrete, ceramics, bones, slag, charcoal, organic matter, limestone fragments and metals. Horizons enriched in slag fragments are also high in metals: $\mathrm{Fe}, \mathrm{Mn}$ and $\mathrm{Pb}$, which reveal a twofold increase in metal processing activity.
\end{abstract}

Keywords: Wisła River valley, river deposits, made ground, pollen analysis, chemical and mineralogical analysis, radiocarbon dating, environmental changes.

\section{INTRODUCTION}

Taking advantage of an opportunity (rather unique in large city downtowns) for tracking the evolution of environment from natural to entirely transformed by human

Corresponding author: T. Sokołowski

e-mail: tsokol@uci.agh.edu.pl

ISSN 1897-1695 (online), 1733-8387 (print) (C) 2008 GADAM Centre,

Institute of Physics, Silesian University of Technology.

All rights reserved. activity, the authors carried out geomorphological, archaeological, palynological, mineralogical, geochemical studies as well as radiocarbon dating of sediment exposed in a construction excavation made in the backyard of an apartment house in the 7 Krupnicza Street located in the Piasek quarter - one of the oldest parts of historical downtown of Kraków (Fig. 1). Such a wide variety of methods could be applied due to the existence of natural 


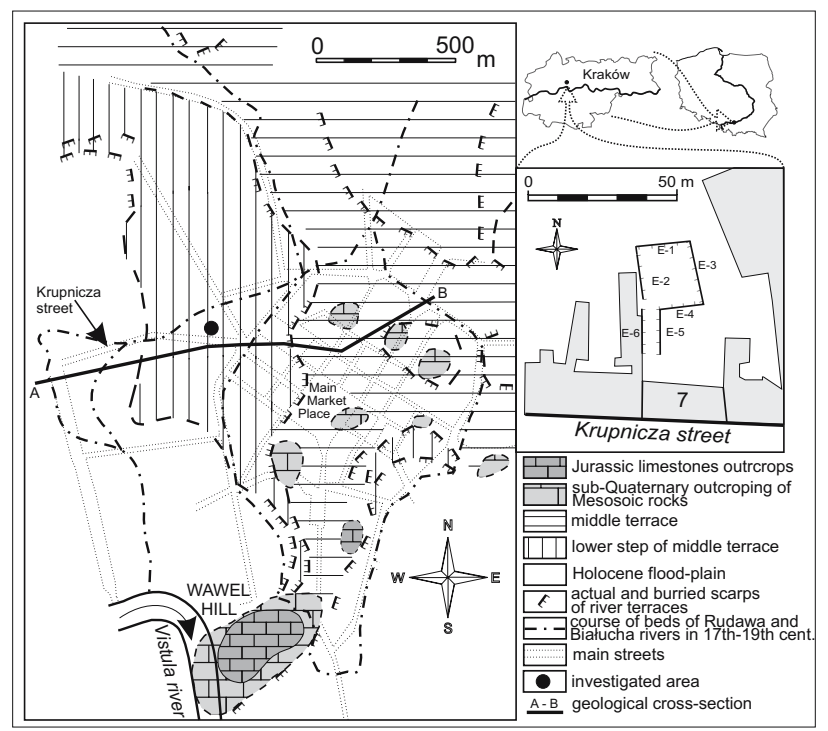

Fig. 1. Location of studied area against the geomorphic sketch of fragment of Vistula river valley (according to Setmajer, 1973 - modified).

deposits beneath the made ground. As the unified methodology suitable for such research does not exist, as yet, methods applied in the following project are proposed as a standard for studies on co-existing, natural and anthropogenic sediments. Application of these methods allowed to accomplish the goals of the project: (i) reconstruction of environment evolution recorded in the sediments since the last glacial epoch and (ii) determination of the chronology of noted events. The results are valuable also because such comprehensive research has not been undertaken up to date in Kraków, despite the importance of that city as one of the oldest and the most prominent settlement centres in Poland.

\section{STUDY AREA}

The walls of the 4-meter-deep excavation (marked No.1-4) were oriented NNW-SSE, WWS-EEN and N-S (No. 5, Fig. 1). Generally, in all the walls the same stratigraphic sequence was observed: alluvial sediments (TD) $>$ black soil $(\mathrm{BS})>$ made ground (MD). From the bottom of the made ground rectangular holes of various depths protruded into the underlying strata (Fig. 2). Some were filled with livestock (mostly cows and goats) bones and horns. Locally, made ground was underlain by peatlike, grey soil and/or sand.

The recent surface of the made ground is located at the altitude of 206.2-207.2 $\mathrm{m}$ a.s.l. whereas the top surface of river terrace occurs at 203.2-204 m a.s.1. Similar values were reported by Radwański (1975) and, partly, by Jamka (1963).

The oldest settlements recognized at archaeological sites located in the close vicinity are dated back to the Early Medieval period (9th century - Jamka, 1963; Radwański, 1975; Wałowy, 1986). Between the 14th and the 16 th centuries AD the Garbary village had existed here as the suburb of ancient Kraków. Garbary played an important role in the city's economy as a servicing and handicraft centre (see e.g. Pieradzka, 1931; Wiśniewski, 1986b; Laberschek, 2005) where tanneries, fullers, bleacheries, breweries, metal grinderies, pottery and silver melting workshops have been operating. Power was provided by water mills supplied by canals connected to the Rudawa River. Digging of canals has started in the mid 13th century (cf. Krasnowolski, 2003). One of such canals, which was the arm of the Rudawa River run some 40-50 meters north from the described site.

\section{RESEARCH METHODS}

Lithology of alluvial sediments was recognized by field observations and measurements of sedimentary structures. Petrographic composition was determined for several fractions obtained with a set of screens differing by $1 \Phi$. Sand fraction $(0.8-1.0 \mathrm{~mm})$ was analyzed for roundness and frosting of quartz grain surfaces, according to the method proposed by Mycielska-Dowgiałło and Woronko (1998). This analysis combines the roundness after Krumbein's scale (Krumbein, 1941) and the character of grain surface. The lowest organic layer encountered in the erosional washout was radiocarbon-dated. Simultaneously to structural and textural studies of natural sediments, archaeological artefacts were searched and collected.

As the methodology of made grounds studies compatible with mineralogical, petrographic, geochemical and environmental methodologies (Pawlikowski, 1992; Gworek et al., 2000) has not been established, as yet, procedures applied in geological (Lamparski, 1992), soil (Karczewska and Kabała, 2005), made grounds (Pisarczyk, 2004) and archaeological (Renfrew and Bahn, 2000) research were used.

Grain size analyses (both dry and wet) were run for sand fraction using the polyethylene screens, avoiding the crushing of aggregates. For each of the sample, moisture, loss on ignition, $\mathrm{pH}$, specific electric conductivity and Eh were measured. Comparison of the results of dry and wet analyses provided data on sediment aggregation which, in turn, informed on saturation of made ground with solution of TDS higher than that of meteoric waters.

Mineralogical observations were made with the POLMI-2 polarization microscope for fraction $0.2(0.18)$ - $0.5 \mathrm{~mm}$, which occurred in representative quantities in all studied samples. In this fraction all components were inspected, particularly those of anthropogenic provenance. Quantitative data were obtained with the point counting method (ELTINOR counter). In each sample about 500 grains were counted.

For chemical composition fraction $<0.18 \mathrm{~mm}$ was treated with concentrated nitric acid and boiled at $130^{\circ} \mathrm{C}$ for 2 hours. Obtained extracts were analyzed with the AAS method (PYE UNICAM SP-9 instrument).

Samples for pollen analysis were collected from black soil and peat-like deposits as well as from thin organic intercalation, from soil aggregates found in channel washout and from grey soil. From each sample $1 \mathrm{~cm}^{3}$ of sediment was prepared with the modified Erdtman's acetolysis method. Sediment was pre-treated with HF acid to remove mineral components.

Obtained results were presented in a form of percentage pollen diagrams. Percentage value of each individual 
taxon was calculated in relation to the total sum consisted of a sum of arboreal and non-arboreal pollen, excluding pollen of local plants: limnophytes, telmatophytes, as well as spores of Pteridophyta and Sphagnum.

\section{RESULTS}

The results are described in an order, which generally reflecting the succession of particular stratigraphic layers. The layers were marked with symbols (Fig. 2).

\section{Natural deposits}

Two lower members of the succession provide the natural background of human activity, namely the alluvial terrace deposits (TD) and black soil (BS). The former member (TD in Figs 2 and 3) observed at the bottom of excavation usually comprises medium- and coarsegrained sands with scarce gravel grains $\left(\Phi_{\max }=3 \mathrm{~cm}\right)$. Locally, especially along the wall No. 5, sands reveal medium-scale (up to $30 \mathrm{~cm}$ thick) planar cross-bedding (Sp lithofacies), which can be linked to flat, transversal bars (2D). Such forms combined with angular base contact indicate deposition from shallow flows of decreasing flow intensity. More common are massive structure sand (Sm lithofacies) of undefined origin although diffused boundaries between both lithofacies and their lateral contacts seem to suggest the origin of $\mathrm{Sm}$ lithofacies from post depositional processes. The main component of sands is quartz (95.9\%) accompanied by feldspars, micas and fragments of limestone and crystalline rocks (Fig. 4). Quartz grains show matt surfaces (91.8\%) shaped in aeolian environment (RM and EM/RM - Table 1).

Sands are overlain with continuous layer of black soil (Mollic Gleysols - BS - Fig. 2). Its fabric is medium- and coarse-grained, locally silty sand. Palynological analysis revealed slight dominance of tree pollen (Fig. 5, part A, phase I), mostly with predominance of pine (Pinus sylvestris - max. 46.8\%) and oak (Quercus - max. 8.1\%). In almost all samples low amounts of spruce (Picea abies), fir (Abies alba), lime (Tilia), poplar/aspen (Populus), alder (Alnus) and maple (Acer) pollen were noticed. Among herbs high percentage of grassland species were

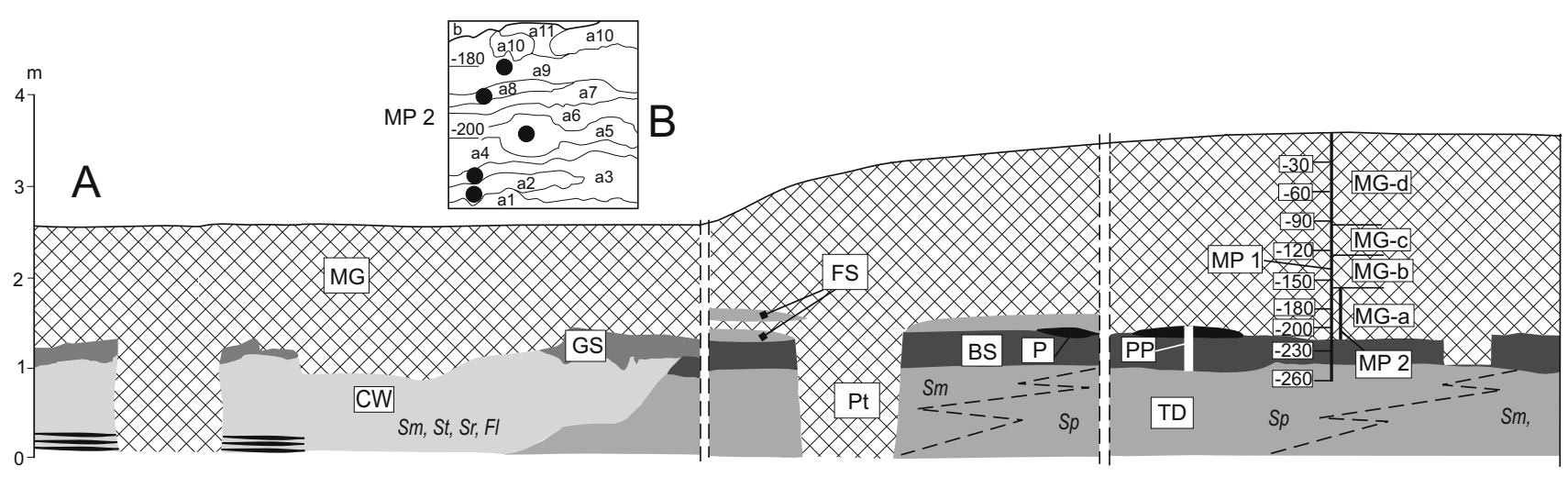

TD - terrace deposits, BS - black soil, CW - channel washout, GS - grey soil, P - peat or organic loam, FS - flood sand, MG - made ground, Pt - pit, MP - mineralogical profile, PP - palynological profile,Sm, Sp. St, Sr, FI - code of lithofacies,

Fig 2. Schematic logs of deposits.

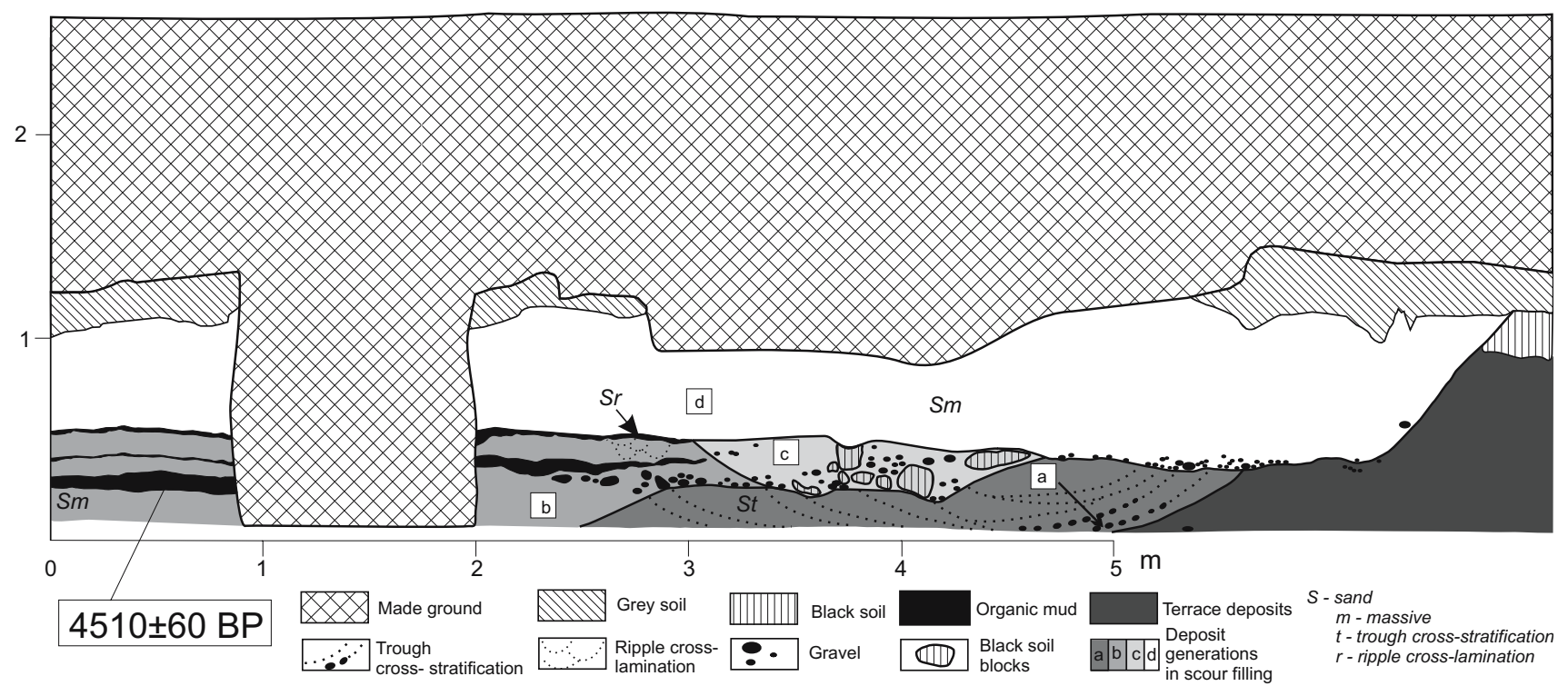

Fig. 3. Deposits in channel washout. 
Table 1. Classes of rounding of quartz grains.

\begin{tabular}{lrrrrrrrr}
\hline & NU & EL & RM & EM/EL & EM/RM & C & O & \multirow{7}{c}{$\Sigma$} \\
\cline { 2 - 7 } & \multicolumn{7}{c}{$[\%]$} \\
TD & 0.7 & 0.0 & 4.5 & 3.0 & 87.3 & 2.2 & 2.2 & 134 \\
CW-a & 0.0 & 0.0 & 0.0 & 52.1 & 37.0 & 5.5 & 5.5 & 146 \\
GS & 0.8 & 0.0 & 0.0 & 24.4 & 55.7 & 2.3 & 16.8 & 131 \\
FS & 0.0 & 0.0 & 1.7 & 10.8 & 71.7 & 1.7 & 14.2 & 120 \\
\hline
\end{tabular}

1. NU - fresh surface, angular (Krumbein roundness 0.1-0.2);

2. EL - round, shiny surface (roundness $0.7-0.9$ );

3. RM - round, matt surface (roundness $0.7-0.9$ );

4. EM/EL - intermediate, shiny surface (roundness 0.3-0.6);

5. EM/RM - intermediate, matt surface (roundness 0.3-0.6);

$\mathrm{C}$ - broken, this group includes grains with at least a $30 \%$ loss of the original surface;

$\mathrm{O}$ - others.

observed, e.g. Centaurea cyanus, Centaurea jacea (max. $12.8 \%$ ) and Centaurea scabiosa, as well as Filipendula, Trifolium-t, Ranunculus, Thalictrum, Lychnis-t. and Cirsium, and/or Carduus. Common were also pollen grains of taxa of wide ecological tolerance, e.g. Poaceae, Cyperaceae, Cichorioideae and Apiaceae. Pollen spectra demonstrated also significant amounts of ruderal plants and weeds: Polygonum aviculare, Artemisia, Urtica, Brassicaceae and Chenopodiaceae, which suggests local presence of farm buildings or houses. In several samples Anthoceros punctatus was encountered, which is e.g. an indicator of existence of fields. Apart from agriculture indicators, i.e. pollen of cereals (mostly Triticum-t., rarely
Secale cereale, Avena-t., Hordeum-t.) and buckwheat (Fagopyrum), some Poaceae, Brassicaceae, Chenopodiaceae or Apiaceae representatives might also have originated from cultivated plants. Characteristic weed accompanying the winter crops is cornflower (Centaurea cyanus). It is suggested that during deposition of studied sediments the vicinity of the site was unforested although some tree clusters were present. Locally, grasslands (meadows and/or pastures) occurred. Some areas used as corn fields could be temporary utilized as gardens. Studies revealed coexistence of plants inhabiting dry (e.g. Centaurea scabiosa, Calluna vulgaris, Rumex acetosella, Pteridium aquilinum), wet (Caltha, Phragmites, Typha latifolia, Sphagnum, Thelypteris palustris) or aquatic (Lemna, Potamogeton, Stratiotes aloides) habitats. This may advocate both the local diversification of biotopes and/or the intentional or casual collection of plant material derived from various sources. In soil rare ceramic artefacts were found, typical of the Early Medieval period (Fig. 6). Interesting is the discovery of flint artefact - a hafted knife made of Jurassic flint originating from the vicinity of Kraków, which shows features of decadent flint knapping typical of the Bronze Age (Fig. 7).

Other anthropogenic components of soil are charcoal and slag fragments found in large amounts along the full studied succession (Fig. 4). Slag fragments are grey, low in glassy material, which may suggest low processing temperatures. Slag is always accompanied by charcoal fragments. Small amounts of brick fragments were also observed. Soil reveals decreased $\mathrm{pH}$ and high contents of
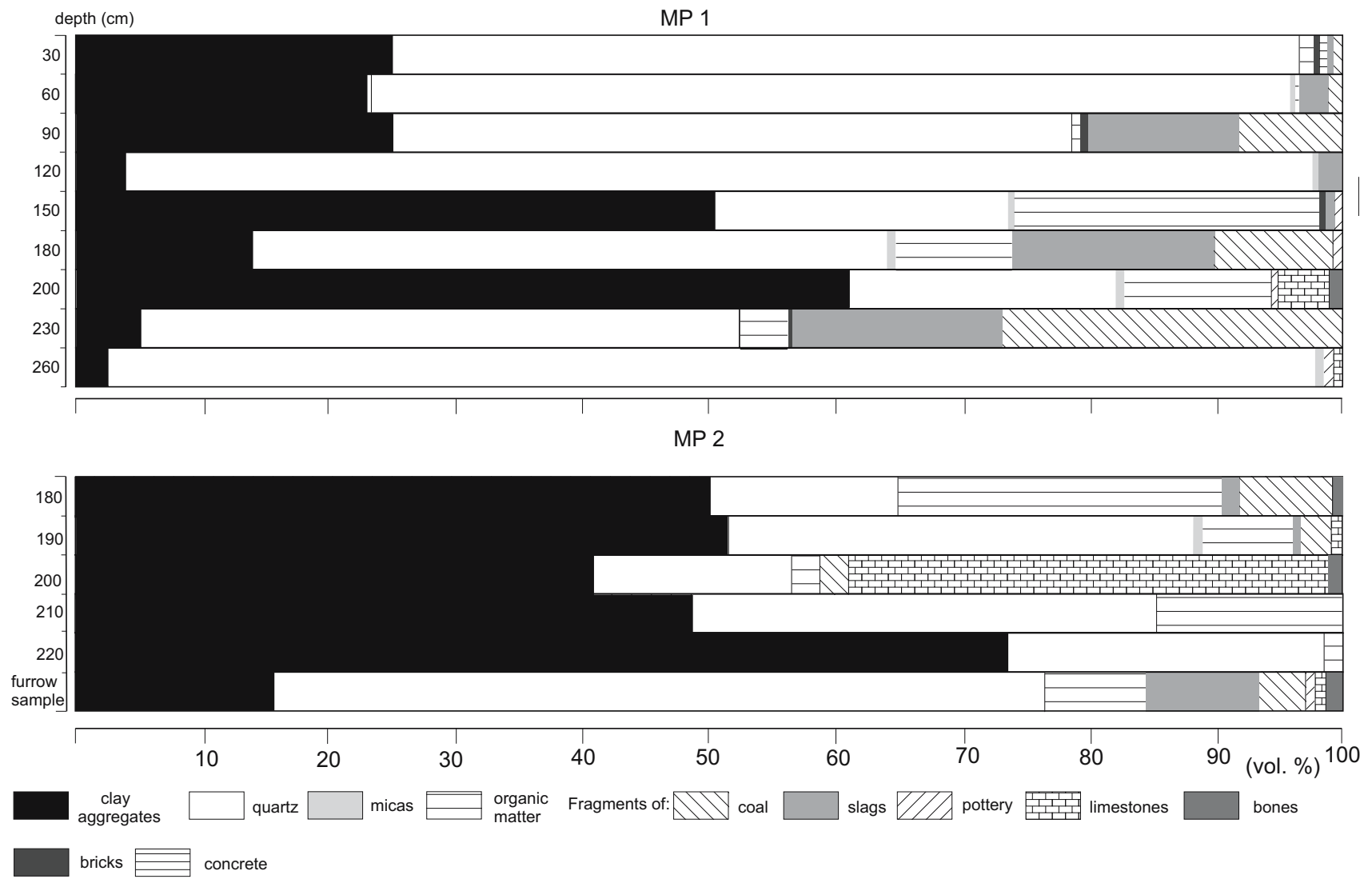

Fig. 4. Contents of minerals and artefacts in made ground. 


$\mathrm{Cr}$ as well as increased amounts of $\mathrm{Zn}, \mathrm{Pb}$ and $\mathrm{Fe}$ (Figs 10-12).

In the northwestern part of excavation, in No. 1 and 2 walls a clear channel washout was encountered (CW in Fig. 2). The washout cuts both the older alluvial sediments and the black soil. The filling deposits formed several layers separated by erosional surfaces. Their bottoms remain unexposed, except for the highest layer in this succession. The oldest layer is sand, rarely gravely sand with medium-scale, trough cross-bedding ( $S t$ and $S G t$ lithofacies - layer a, Fig. 3). Such structures are related to three-dimensional megaripplemarks, which originated from bottom rhythmic transport in deeper flows of higher energy. Quartz grains indicate variable roundness but dominating are shiny grains (EM/EL Table 1) typical of high-energy aquatic environment.

Petrographic composition of river gravels from the vicinity of Kraków shows domination of sandstones originating from the Flysch Carpathians and flints derived from eroded Jurassic limestones of the Silesian-Kraków Upland but quartz from other sources is also present. Other clastic components: Jurassic limestones, Carpathian lydites as well as igneous and metamorphic rocks of glacial origin occur in small amounts. Petrographic composition of gravels representing $S G t$ lithofacies allows to precise the time of their accumulation between deposition of gravels of the Holocene Vistula River terrace (Bielanysee Rutkowski and Sokołowski, 1983) and deposition of the Rudawa River gravels from the Budryk Street which were laid down during the last glacial period (Fig. 8). Hence, sediments from the Krupnicza Street can be classified into the Rudawa River Holocene gravels. Subsequently, these sediments were eroded and succeeding layer deposited in erosional channel shows more complex structure (layer b - Fig. 3). Its lowermost part is a massive structure sand ( $\mathrm{Sm}$ lithofacies). After its sedimentation the washout evolved into the oxbow bend in which periods of water stagnation resulting in deposition of organic muds were interrupted by episodes of low-energy flows (lower part of lower flow regime) with the accumulation of fine and medium sands with local ripplemark lamination ( $\mathrm{Sr}$ lithofacies) formed in shallow, low-energy channels.

Pollen analysis of the lowermost mud layer (part B, sample - K-OG - Figs 2, 5) revealed the domination of tree pollen, mostly Pinus sylvestris $(70.5 \%)$ with smaller amount of Picea abies (6.0\%), Alnus (3.6\%), Abies alba $(2.4 \%)$, Tilia $(1.0 \%)$ and Betula (3.4\%). The undergrowth contained mostly fern (Filicales monolete $-30.8 \%$ ) and bracken fern (Pteridium aquilinum). Herbaceous plants reveal low taxonomic diversity. The most common are pollen of Poaceae $(3.8 \%)$ and Cyperaceae $(2.2 \%)$. These results allow suggesting that during deposition of muds the area was covered with pine forest, possibly with small Picea admixture. The sample deposition was dated back to the $4510 \pm 60$ uncal. years BP (Gd-12724 - Table 1).

In the uppermost mud layer (part B, sample Kr-m, Figs 2, 5) palynological analysis showed different character of vegetation, i.e. low percentage of tree pollen: Pinus sylvestris (27\%), Picea abies (2.6\%), Quercus (2.6\%), Tilia (4.6\%) and Corylus (2.6\%) as well as high representation of herb pollen with numerous ruderal plants and

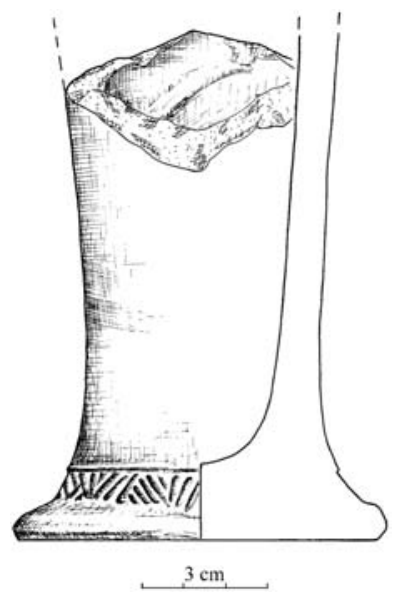

Fig. 6. Reconstruction of ceramic utensil from black soil.

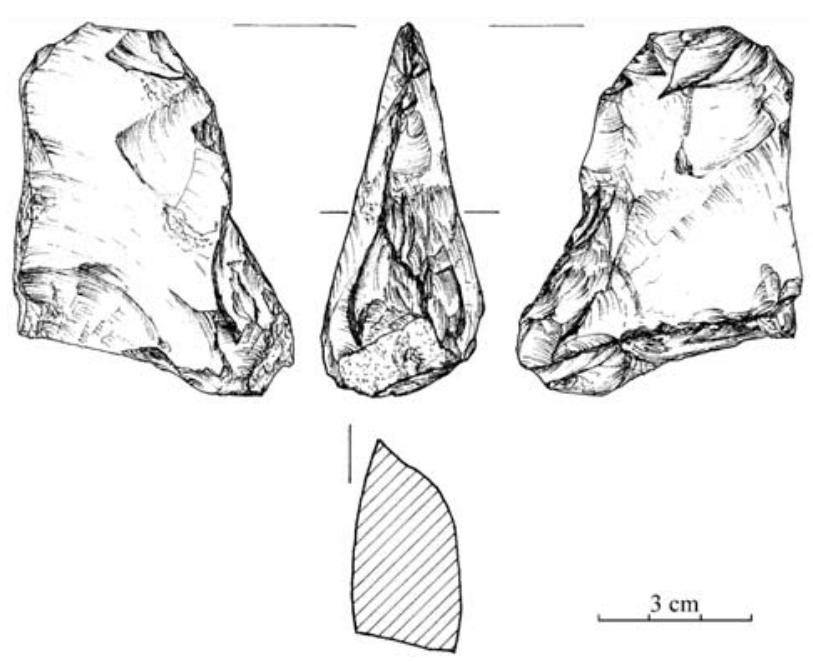

Fig. 7. Bronze Age flint tool from black soil.

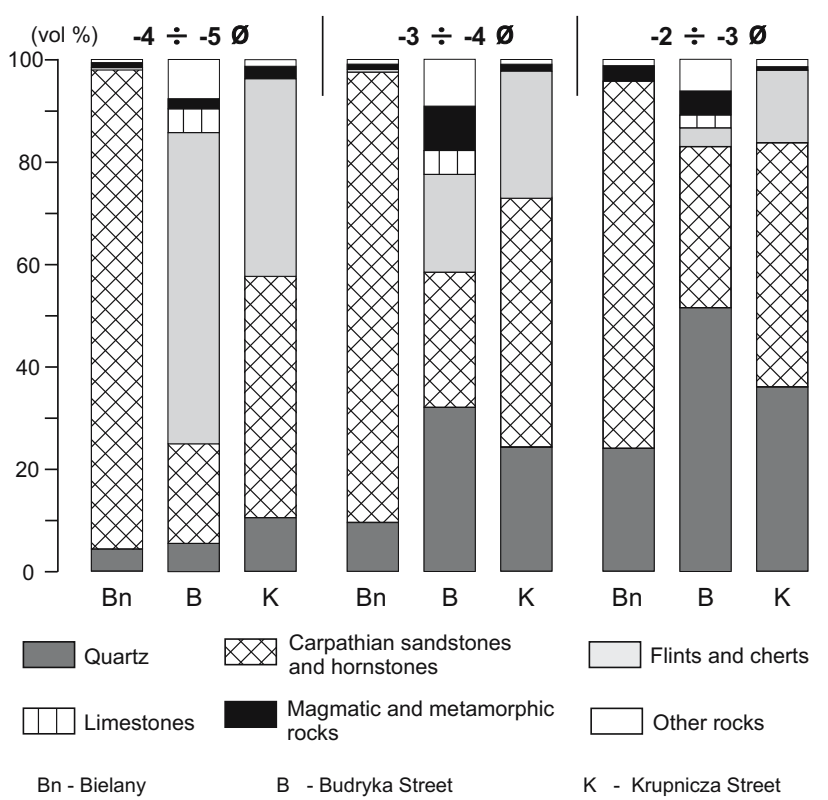

Fig. 8. Petrographic composition of gravels from washout filling. 
weeds: Centaurea cyanus (4\%), Brassicaceae (5\%) and Artemisia (2\%). High frequencies of grassland taxa: Poaceae, Cichorioideae, Apiaceae, Centaurea jacea and Hypericum were noticed. Crops were represented only by wheat pollen grains (Triticum-t., $2 \%$ ). It is concluded that accumulation of upper mud layer took place in quite open environment, in the neighbourhood of meadows and small arable fields.

The erosional surface cutting the uppermost mud layer and local sand accumulations was covered by sand with small admixture of fine gravel (layer c, Fig. 3). Very interesting feature is the presence of lumps, up to $20 \mathrm{~cm}$ across, composed of black soil, identical with described above. Pollen spectra of lumps (part B, sample Kr-b, Figs 2, 5) revealed quite high percentage values of trees, mostly Pinus sylvestris $(44.4 \%)$ as well as grassland plants, usually Cichorioideae (28\%) and Centaurea jacea (9\%). Small amounts of Centaurea cyanus (2\%) and single pollen of Triticum-t. were noted. Such composition points to the local presence of meadows and, possibly, crop fields.

Deposition of succeeding layer (d - Fig. 3) was preceded by lateral erosion and expansion of the washout. Almost flat erosion surface, which levelled the underlying sediments was covered by coarse and medium sand of massive structure ( $\mathrm{Sm}$ lithofacies) with locally developed layer of channel pavement composed of fine gravel $\left(\Phi_{\max }=2.5 \mathrm{~cm}\right)$. Deposition was fast and the increasing load from overlying sediments resulted in the formation of unstable density bedding reflected in minor bending of mud layer and local folding of underlying sand layer.

Along the wall No. 1, above the black soil and, locally, also above the sand filling of the washout, a $25-\mathrm{cm}$-thick layer of grey, silty sand was found (GS in Figs 2 and 3). It shows features of initial soil, as confirmed by high percentage of chemically corroded grains $(16.8 \%)$ resulting from the action of humic acids (class $\mathrm{O}$ - Table 1).

Palynological analysis of these sediments (part B, sample KII-G, Figs 2, 5) demonstrated very low percentage of tree pollen (mostly Pinus sylvestris - 16.7\% and Quercus - 3\%). Among herbs single pollen grains of cultivated plants: Triticum-t. and Cannabis sativa were observed but the most common were: Artemisia (3.0\%), Brassicaceae (4.8\%), Poaceae (11.2\%), Cyperaceae (8.9\%), Cichorioideae (11.2\%), Apiaceae (5.9\%) and Centaurea jacea-t. (11.5\%). These results suggest accumulation in an environment totally transformed (deforested) by human activity.

In the remaining parts of excavation, particularly in walls No. 3-5, the soil is covered with the made ground or, in some parts, with 20-cm-thick layer of poorly sorted sand (FS in Fig. 2) with rare gravel pebbles $\left(\Phi_{\max }=1.5 \mathrm{~cm}\right)$. The sand of $S m$ lithofacies laterally grades into the $S p$ lithofacies (planar cross-bedding). Relatively high percentage of matt grains (class RM and EM/RM, Table 1) suggests redeposition of older terrace deposits (TD). In big parts of No. 3, 4 and 5 walls this sand is overlain by $25-\mathrm{cm}$-thick made ground followed by 15 -cm-thick layer of poorly sorted sand, identical with that described above.
Locally, the black soil is directly overlain by dark, organic mud, which grades up the sequence into a dozencm-thick peat-like deposit layer ( $\mathrm{P}$ in Fig. 2). Pollen analysis demonstrated significant differences in both the taxonomic composition and the percentages values of pollen spectra of mud and peat-like deposit samples, in comparison with soil. It enabled to distinguish a separate pollen zone marked as phase II in the diagram (Fig. 5, part A, phase II). Analyzed samples showed high percentage of tree pollen (up to $62 \%$ ) with dominance of Pinus sylvestris (max. $38.3 \%$ ), and Quercus (max. 6.5\%), Alnus (max. 6.1\%), Abies alba (max. 4.4\%), and Corylus (max. 2.2\%). Birch pollen constituted up to $5.2 \%$ but such a low percentage excludes the occurrence of this tree "on site" (see Ralska-Jasiewiczowa et al., 2004). Moreover, pollens of Carpinus betulus, Tilia, Populus, Salix, Fagus sylvatica and Juglans regia were identified. Characteristic feature of phase II was very high content of cereals, particularly Triticum-t. (max. 12.0\%), Secale cereale (max. 5.0\%), Avena- $\mathrm{t}$ (max. 2.2\%) and Hordeum-t. (max. 2.0\%). Single pollen grains of Cannabis sativa and Fagopyrum were noted, as well. Ruderal plants and weeds were less common: Centaurea cyanus (max. 0.7\%), Chenopodiaceae (max. 2.7\%), Brassicaceae (max. 1.0\%) and Spergula-t. Also pollen of Artemisia was present in all samples, although in small amounts. A few pollen grains of Polygonum aviculare-t were noticed whereas grassland taxa were represented by Poaceae (max. 17.1\%), Cichorioideae, Ranunculus-t., Lychnis-t., Centaurea jacea-t., Apiaceae and others.

In the course of sedimentation of phase II, the site vicinity was still open with single trees growing (pine, oak, alder, hornbeam, fir, spruce and walnut Juglans regia). High percentage of cereal pollen compared with the lack of coexisting cornflower suggests that this pollen were locally overrepresented due to e.g. temporary harvest or straw storage. Peat-like deposit and dark mud are not the floodplain sediments but were formed in the shallow, local lowerings or hollows filled up partly with anthropogenic material.

Contemporaneous formation of grey soil in more dry environments cannot be neglected. The study area was intensively used as e.g. storage or waste disposal. The surrounding area was covered mostly by meadows and pastures inhabitated by representatives of grasses, sedges, accompanied by Centaurea jacea, C. scabiosa, Hypericum, Ranunculus and Filipendula as well as by fields of wheat, hemp, buckwheat or vegetables. Some pollen grains of Brassicaceae or Apiaceae might have originated from vegetable plants planted in the gardens.

\section{Made ground}

The made ground forms a continuous layer of variable thickness (up to 2.6 meters in wall No. 5) which covers the above described natural deposits. Diversified lithology allowed to distinguish several layers (Fig. 2): MG-a - dark, loamy, with organic matter and lightcoloured streaks, containing small limestone fragments, MG-b - light-coloured, containing rounded loam fragments, MG-c - light-grey, of rough top surface, locally 
containing limestone fragments, MG-d - dark, loamy, with organic matter and brick fragments.

Sampling of the made ground was completed along two lines. The longer sampling line (MP 1) included specimens collected from depths $30,60,90 \mathrm{~cm}$ (MG-d), $120 \mathrm{~cm}$ (MG-c), $150 \mathrm{~cm}$ (MG-b), 180 and $200 \mathrm{~cm}$ (MG-a) below surface. The shorter sampling line (MP 2) included only the layer a in which lithological diversification was more evident. The following layers were observed: MG-a1 - grey, loamy, with organic matter, MG-a2 - lighter, occasionally with pink or red shades and with traces of burning, MG-a3 - black, with charcoal fragments, MG-a4 - light, with organic matter and small limestone fragments, MG-a5 - light, with large limestone fragments, MG-a6 - light, with small limestone fragments, MG-a7 - black, with organic matter, MG-a8 light, with limestone fragments, MG-a9 - black, loamy, with organic matter, MG-a10 - crushed bricks, MG-a11 dark, loamy, with organic matter. From this succession a channel sample was collected as well as point samples from depths: $180 \mathrm{~cm}$ (MG-a9), $190 \mathrm{~cm}$ (MG-a8), $200 \mathrm{~cm}$ (MG-a5), $210 \mathrm{~cm}$ (MG-a3) and $220 \mathrm{~cm}$ (MG-a2) below surface were taken.

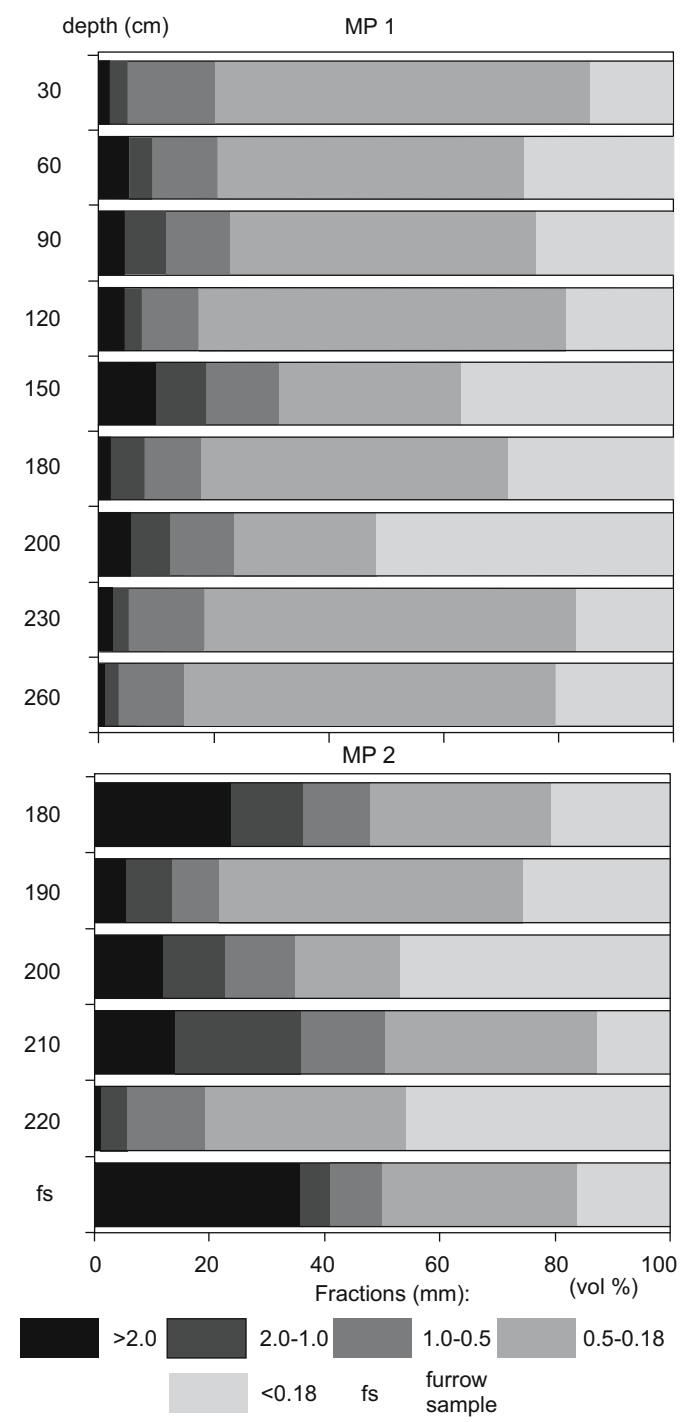

Fig. 9. Grain-size composition of made ground (dry deposits).
Grain size distribution indicated that highest amounts of coarse fraction $(>2 \mathrm{~mm}$ ) related to aggregation appears at depths $-150,-120$ and $-200 \mathrm{~cm}$ of the MP 1 line, and at depth -210 of the MP 2 line (Fig. 9). This may point out to more intensive human activity in that period.

Fraction $<0.2 \mathrm{~mm}$ content is usually less than $60 \%$, excluding the depth $-220 \mathrm{~cm}$ of the line MP 2 in which it raises to $90 \%$. It is possible that local inundations took place during deposition of this layer.

Mineral composition of made ground is similar along both lines and includes quartz, clay minerals and micas (Fig. 4), and anthropogenic components: fragments of bricks, concrete, bones, slag fragments and charcoal pieces as well as angular limestone fragments. The anthropogenic components constitute usually from several to a dozen per cent. Organic matter seems to be mostly anthropogenic although it probably contains some admixture of natural components. For the lower part of the made ground (sampling depth $-200 \mathrm{~cm}$ ) characteristic is the high content of carbonate rock fragments and clay aggregates together with low percentage of artefacts (excluding bones fragments at various stages of transformation). Fragments of compact bones are usually wellpreserved whereas those of spongy bones are filled with organic matter and clay minerals.

The overlying layers (MG-b and c) reveal high compositional variability (Fig. 4) with horizons enriched in organic matter, slag fragments, fragments of ceramics and
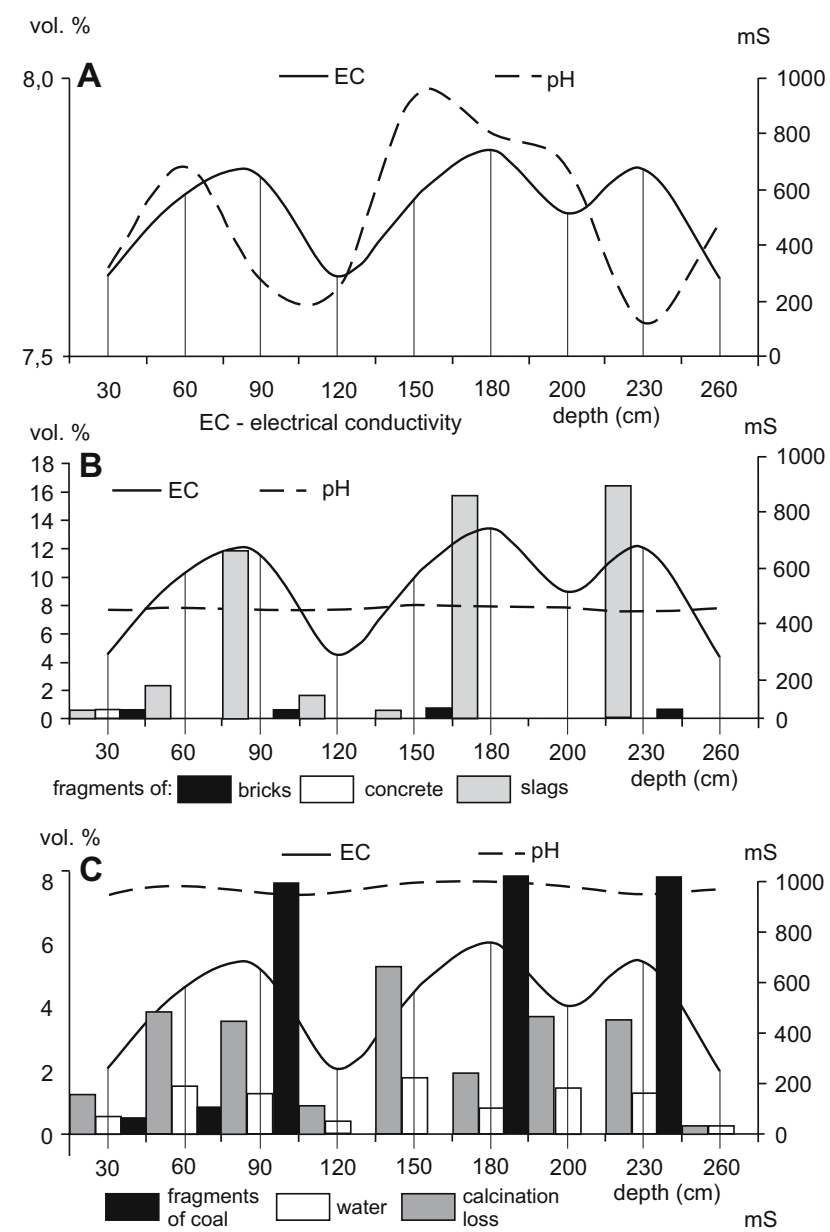

Fig. 10. Variability of $\mathrm{pH}$ and electrical conductivity of made ground. 
bricks or in clay aggregates. In the top part (MG-d) slag fragments dominate whereas higher in the sequence the concrete fragments appear $(0.53 \%$, Fig. 4).

The diversity of made ground is shown also by the results of physical and chemical analyses. Variability of $\mathrm{pH}$ observed in black soil, in the upper part of MG-a layer and in the middle part of MG-d layer (see Fig. 10a) is caused by changes in salt content indicated by specific electric conductivity but $\mathrm{pH}$ values depend also on the content of carbonates which cement aggregates present in many parts of the made ground layer. Finally, the increasing $\mathrm{pH}$ corresponds to the increasing amounts of organic matter, whereas the rising specific electric conductivity is related to the presence of slag and charcoal fragments (Figs 10b-c).

Migration of pollutants in true or colloidal solutions depends on permeability of sediments, which, among others, is a function of grain size. Along the MP 1 sampling line highest percentage of $>0.2 \mathrm{~mm}$ (over $70 \%$, Fig. 9) was found only in the top part and at $-120 \mathrm{~cm}$ depth, and is related to the presence of angular limestone fragments. Limestone is also responsible for the rise of $\mathrm{pH}$ in anthropogenic sediments to over 7.5 whereas literature data for soils indicate values 4.0-7.2.

Highest contents of total heavy metals appear in the youngest (MG-d) layer, particularly at depths -60 and $-90 \mathrm{~cm}$. Similar values were found also in the MG-a layer at depth $-180 \mathrm{~cm}$. Highest contents of $\mathrm{Cd}$ and $\mathrm{Ni}$ were noticed in MG-a and b layers (depths -150 and $-200 \mathrm{~cm}$ ), that of $\mathrm{Cu}$ - at the bottom of MG-d (depth $-90 \mathrm{~cm}$ ) and that of $\mathrm{Pb}$ - in the MG-a layer (depth $-180 \mathrm{~cm}$ ) as well as in black soil (BS, depth $-230 \mathrm{~cm})$. Along the MP 2 sampling line highest pollution with heavy metals occurs at depths $-18 \mathrm{~cm}$ (layer MG-a9), $-190 \mathrm{~cm}$ (MG-a8 layer) and $-210 \mathrm{~cm}$ (MG-a3 layer).

Enrichments in $\mathrm{Fe}$ and Mn along the MP 1 sampling line was observed in layers MG-a, MG-d and in the black soil (depths $-30,-60,-90,-180$ and $-230 \mathrm{~cm}$, Fig. 12b)

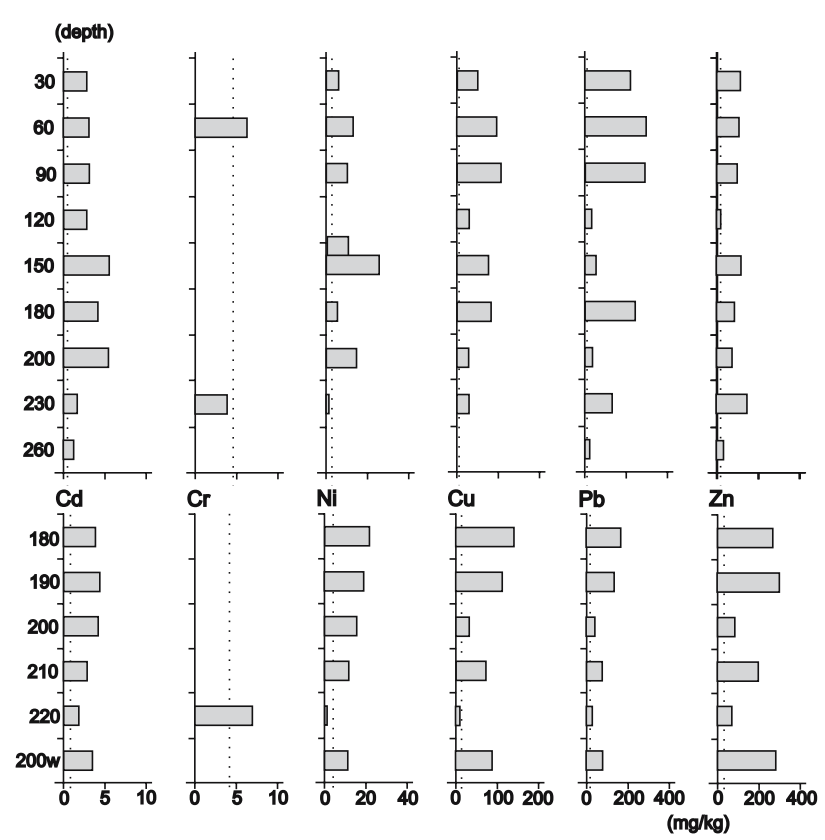

Fig. 11. Contents of metals in made ground. whereas along the MP 2 line such values were found in the upper part of the sequence as well as at $-220 \mathrm{~cm}$ depth (MG-a2 layer). The appearance of various contents of heavy metals at various depths of made ground succession suggests diversified sources of their origin.

Characteristic is the increase in the number of microartefacts (particularly slag pieces) with the increasing contents of $\mathrm{Fe}, \mathrm{Mn}$ and $\mathrm{Pb}$ (Fig. 12b). Apparently raised content of $\mathrm{Ni}$ in the layer MG-b (depth $-150 \mathrm{~cm}$ ) compared with general depletion of that layer in heavy metals is difficult to explain.

It must be emphasized that basic reaction of anthropogenic sediments and contained organic matter, which increase their sorptional potential, as well as fine grain size effectively limit high migration rate of pollutants. Thus, indicated concentrations of heavy metals reflect true, anthropogenic pollution.

\section{CHRONOLOGY AND DIRECTIONS OF ENVI- RONMENTAL CHANGES}

Summing up the results of studies on sediments underlying the made grounds, it should be highlighted that natural land surface (i.e. the top of black soil) corresponds to morphological level of the middle terrace, whose presence in this part of Kraków was suggested by Kleczkowski and Adamczyk (1967) and which was distinguished by Setmajer (1973) - as "the Rudawa River fan, altitude 205-203 $m$ a.s.l." and by KmietowiczDrathowa (1975) - as "the lower level of middle terrace". The two latter authors related formation of this level to the activity of Rudawa River in the Younger Vistulian. Their opinions were fully confirmed by present studies, i.e. by very high percentage of grains reworked in aeolian environment (RM, EM/RM) found in sandy sediments (TD). Moreover, it corresponds very well to the Early
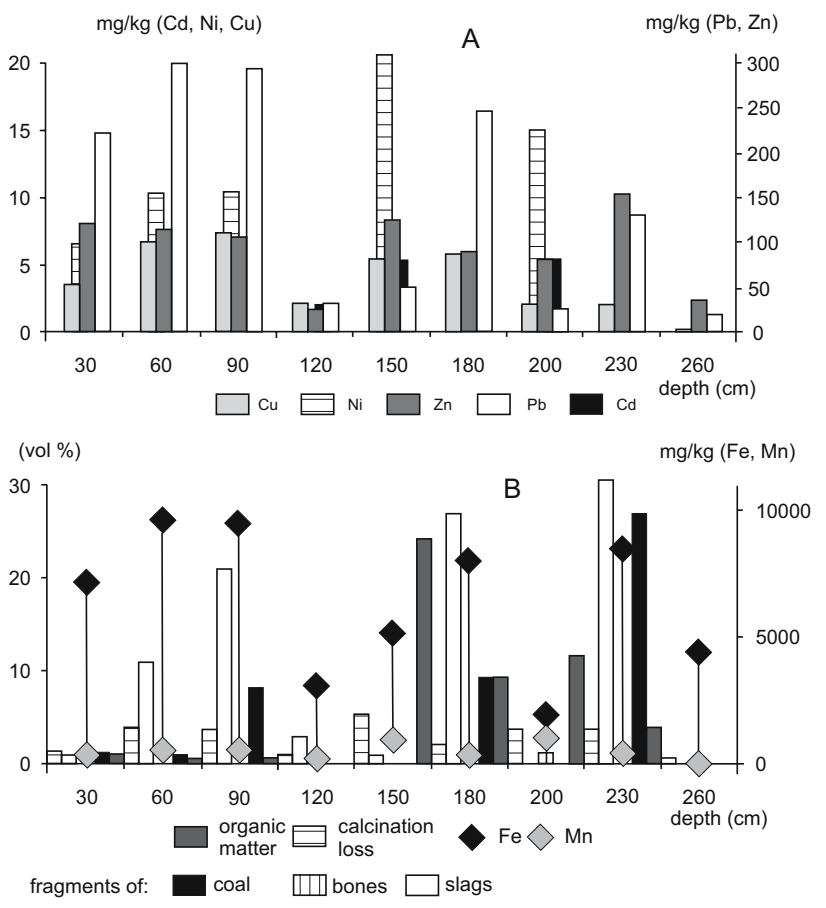

Fig. 12. Content of metals, minerals and artefacts in made ground. 


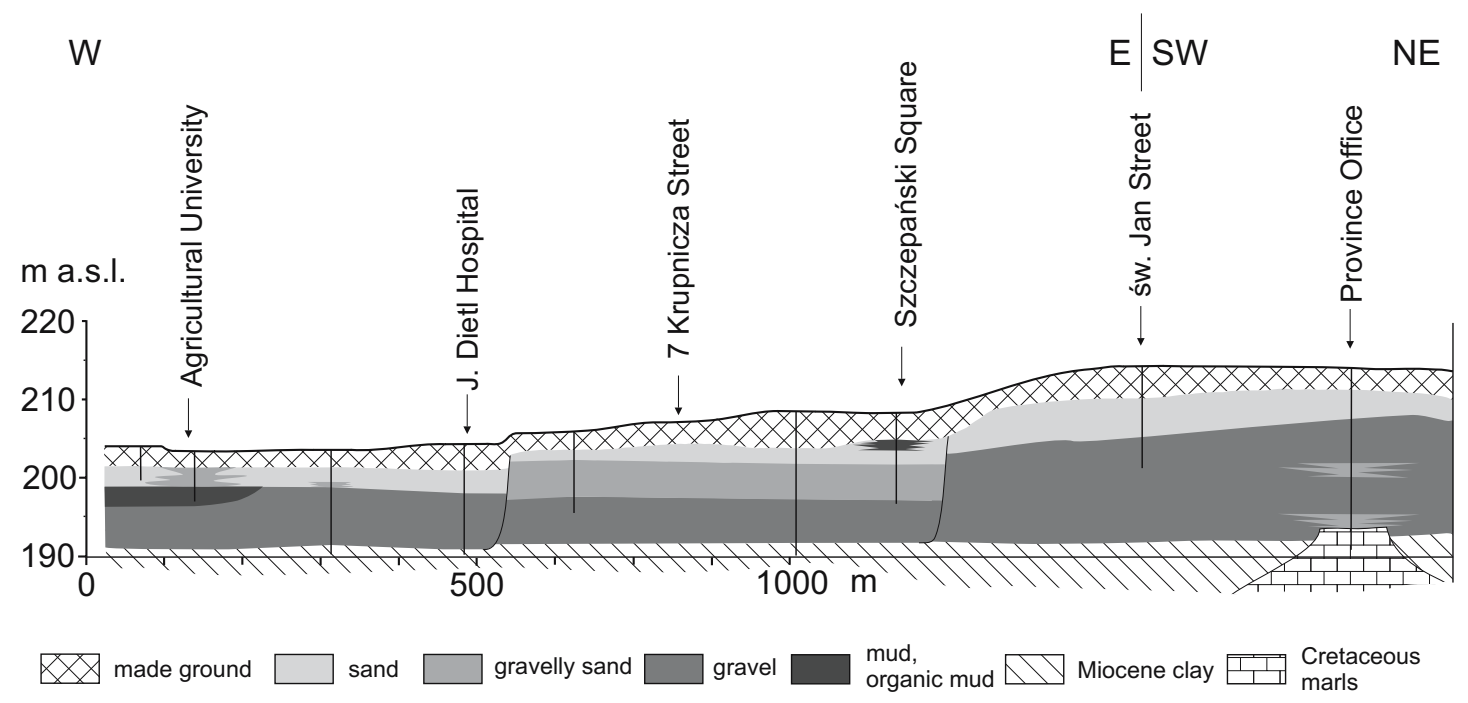

Fig. 13. Geological cross section.

Vistulian age of the upper part of several meter higher (Fig. 13), southern fragment of the Prądnik River fan (see Sokołowski et al., 2006). This fact is contradictory to the opinions of Rutkowski (1987), Starkel (2001) who included the whole area into the Holocene alluvial plain. Such a high percentage of grains affected by aeolian processes indicates that deposition of these strata took place under severe climatic conditions and at poor plant cover (Seppällä, 2004; Goździk, 2007). Wind transported grains were accumulated most commonly at wet bottom surfaces of river valleys or in any morphological depression (Mycielska-Dowgiałło and Woronko, 2004; Goździk, 2007). At low water levels these grains might have been again mobilized by winds (Good and Bryant, 1985; Seppällä, 2004), which contributed to the increasing roundness of grain surfaces. Such evolution scheme of aeolian processes was presented by Goździk (2007) for the end of the last glacial epoch. Zieliński (2007) described similar sediments from Bełchatów and linked them to the end of the Vistulian glacial period.

This level of medium terrace has been dissected here by the ancient Rudawa River since at least the Mesoholocene, as revealed by petrographic composition of gravels in the channel washout. Cutting off the channel and beginning of organic sediments deposition in the area of recent Krupnicza Street was contemporaneous with the younger phase of climate moistening during the transition from the Atlantic to the Subboreal periods (see e.g. Starkel, 2001).

Pollen analysis of the sample from Krupnicza Street proved that at the time of sedimentation the studied area was overgrown by pine woodlands with single spruce and/or fir as well as alder on wetter stands. Low percentages of plant indicators connected with human activity allow suggesting that the land was rather rarely used.

The deposition process radiocarbon-dated to the beginning of the Subboreal period $(4510 \pm 60$ uncal. years BP). When we compare that information about extralocal vegetation with data from other pollen profiles from vicinity of Kraków it is clearly visible that the regional vegetational pattern was different. There is no other palynological data from that time period obtained from Kraków downtown. The closest data come from Cholerzyn peat bog (west from Kraków) and Stanisławice (east from Kraków) sites. It is possible that the uppermost part of the profile PI from Pleszów can be considered too. In the Stanisławice area predominance of deciduous forest communities was noted. The expansion of Alnus was observed as well as changes in the forests composition due to the migration of Carpinus, Fagus and Abies. The role of Pinus was not significant. The human impact on vegetation was marked but did not cause large scale reduction or disturbances of woodlands (Nalepka, 2003). In the neighbouring Pleszów, pollen data from oxbow lake deposit showed the strong destruction of natural vegetation as a result of the exploitation of loess terrace by Neolithic tribes (Godłowska et al., 1987). In the analogical time on the oposite site of Kraków at Cholerzyn the data show that the area was strongly forested. The characteristic feature was high representation of Picea, culmination of Pinus and continuous presence of Abies. Probably pine-spruce-oak woodlands were predominant. Although presence of anthropogenic indicators in the pollen spectra was regular, the changes of vegetation related to human activity were not strong (Madeyska, Obidowicz, 2001). Presented palynological results showed both a diverse character of the local plant cover and a lack of detailed palaeoecological data from the Kraków area.

Geomorphological analysis showed that the washout was affected by episodic flows even in the medieval period.

During deposition of uppermost mud layer the area was overgrown by pine, birch, poplar and alder, which did not form dense woodlands. Ferns settled shady areas. Locally, grasslands could have been used as pastures.

Sands laid down in the upper part of washout succession point to the episodes of rising flow energy and erosion as well as deposition of channel sediments. Interesting products of such episodes are lumps of black soil accumulated in one of layers filling the channel washout. 
Low cohesiveness and water saturation test suggest that soil was transported to the river as frozen lumps. Similar sand and gravel lumps were described from alluvial and fluvioglacial sediments deposited under permafrost conditions (see Mycielska-Dowgiałło, 1998). Neoholocene age of this part of the washout indicates that here the lumps resulted from abrupt rise of water level during the thaw when river eroded still frozen black soil (seasonal permafrost).

The character of pollen spectra from lump samples was similar to those obtained from soil of phase II (Fig. 2, part A), which may suggest that channel flows took place as late as in the 13th century AD.

The range of the black soil deposit on the described terrace is limited. In other excavations located in a distance of 150 metres from the studied site, the black soil was not found (see Wałowy, 1986, 1991, 1995). This type of sediment is characteristic for the lower terrace (floodplain) and is spreaded in west and north-west directions, what is reflected in local names of settlements and villages (e.g. Black Gardens, Black Street, Black Village, see Pieradzka, 1931; Leszczyńska-Skrętowa, 1985a and $b$ ).

It should be emphasized that presented results of palynological analyses of soil samples and overlying peatlike deposit differ significantly from those obtained up to now for Late Holocene peat bogs and oxbow sediments from Kraków vicinity (e.g. Latałowa and Nalepka 1987; Nalepka 1994 and 2003; Madeyska and Obidowicz 2001) but are very similar to the results attained for medieval cultural layers studied in the backyards of houses in the Okół quarter and in the stall in the Main Market (Bieniek et al., 2003 and 2006).

Results of analyses of the PP profile from the Krupnicza Street document strong anthropogenic transformations of local environment during the deposition of studied sediments. Hence, the important factors controlling the pollen spectra might have been the direct human activity and the livestock. It is reasonable to suggest that some pollen could have been brought with plants used as forage, building materials and/or fuel. The presence of ruderal plants growing in the vicinity of settlements, on treaded ground and on subsoil enriched in nitrogen (as Artemisia, Chenopodiaceae, Polygonum aviculare, Urtica and Plantago major) indicates that the area was a settlement zone. High percentage of grassland plants documents vast areas covered by these meadow communities. Some land could have been used for agriculture, as revealed by the presence of cereal and buckwheat pollen. Typical weed accompanying the winter corn was cornflower (Centaurea cyanus). Disturbed soil layers (plough fields) were settled by Anthoceros punctatus. The presence of meadows, gardens and corn fields in the vicinity of Kraków during the Medieval period was confirmed by historical studies (see e.g. - Pieradzka, 1931; Laberschek, 2005).

The results of palynological analyses allow approximating the age of soils and peat-like deposits. High percentage of Centaurea cyanus pollen (up to 3\%) indicates that the black soil formation was completed in the Late Holocene. Previous palynological studies revealed that this weed has been present in Kraków vicinity since about
3200 uncal. years BP, as documented by rare occurrence of its pollen at the Cholerzyn peat bog site (Madeyska and Obidowicz, 2001). Relatively early (about $1870 \pm 50$ uncal. years BP) it appeared in the material from the Stanisławice site (Nalepka, 1994). The burned seed from the Kryspinów site is dated at the Roman Epoch (Lityńska-Zając, 2001). Sporadically, Centaurea cyanus pollen were encountered in layers from the 9th and 10th centuries in Wawel castle (Wasylikowa, 1978) and in cultural layers from the 17 Kanonicza Street site dated at 11th/12th centuries (Bieniek et al., 2003). Expansion of this weed presumably took place in the second half of the 12 th century or in the first half of the 13th century (Koperowa, unpubl. after Wasylikowa, 1978) as proven by numerous cornflower pollen (up to $5 \%$ of total number) identified in late medieval material from the Main Market in Kraków. In this material macroscopic relics of cornflowers were found as well (Bieniek et al., 2006).

Another age indicator of soils is the presence of buckwheat pollen. Archaeobotanical studies conducted in southern Ukraine revealed that Scythians grew this plant about 2500 years ago. However, its economic importance dates back to the Medieval or modern times (LityńskaZając and Wasylikowa, 2005). In the vicinity of Kraków Fagopyrum pollen were rarely observed in layers from the Stanisławice site, probably corresponding to the Roman epoch (Nalepka, 1994) although this dating is controversial (Nalepka, 2003). These pollen grains were also found in the youngest (perhaps medieval) layers at the Cholerzyn site (Madeyska and Obidowicz, 2001). Fagopyrum pollen was encountered in layers from the 11 th/12th centuries in Wawel castle and in the Late Medieval layers from the Main Market in Kraków (Wieserowa, 1979; Bieniek et al., 2006). This plant is also reported in pollen spectra from the neighbourhood of Staszów dated at younger part of the Subatlantic period. This part of the profile can probably be related to the expansion of colonization, which has commenced since the 12th/13th century's transition (Szczepanek, 1971). Fagopyrum seeds have not been identified in materials from Kraków area but macroscopic remains were found in layers from the 9th century in Wolin and as seed accumulations in cultural layers from the 14th century in Kołobrzeg (Badura, 1999).

Apart from pollen data, the indications of human activity in soils are slag and charcoal fragments, which document natural fires or usage of wood and fire by humans. Composition of metal set is typical of the Bronze Age, hence, metals smelting and processing might have been run in the vicinity of the study area. Soil contains also fragments of bricks and ceramics. Sands which locally cover the soil can be related to floods known from the 13th and the 14th centuries when water level rise belonged to the highest in the city history. Peat-like accumulations point out to the presence of small, shallow depressions. Summing up, the completion of soil formation is quite well-dated (13th, locally 14 th centuries) but the beginning of this process is a matter of discussion due to the fact that soil is a layer of distinct stratigraphic condensation, which collects artefacts and ecofacts from various epochs. Although the pollen spectra clearly suggest the relation of soil formation to the Medieval period 
of intensive human activity, the presence of artefacts (flint tools and metals) from the Bronze Age (if these are not secondary accumulations) does not preclude the earlier beginning of soil formation.

The made ground, which covers the natural layers is a waste dump. Microartefacts found in this material are not indicative except for slag and charcoal fragments. Their co-existence may confirm the activity of metallurgical workshops (metal smelting and grinding) mentioned by historians (e.g. Pieradzka, 1931) but may also document ancient fires. Chemical analyses indicate that layers containing slag fragments are also enriched in metals, particularly iron and lead. Interesting is also the layer in which bone fragments were found (excluding the holes where bones were dumped).

Fragments of ceramics, glass and concrete encountered in upper levels of the made ground indicate that its formation has lasted since the 15 th century until recently. Similar succession of layers was found during archaeological studies at the 26 Krupnicza Street site (Wałowy, 1986) and in the gardens of the Carmelitan church and monastery in the Piasek quarter (Wałowy, 1990). However, the formation of made ground since the 15th century evidences the intensive colonization at that time whereas the results obtained by Wałowy (1986) point out to earlier colonization phase (13th-14th centuries).

Almost undisturbed pattern of cultural layers and rare macroartefacts observed at the study site suggest that the area has never been build over with stone or brick buildings but small, wooden outbuildings could exist. It is confirmed by historical cartographic materials (see e.g. Traczewska-Białek, 1981) and by iconography. The backyard of the 7 Krupnicza Street residence could be used as a garden or pasture and/or as a forage store, then as a waste dump.

\section{SUMMARY AND CONCLUSIONS}

1) The study area is located within one of the lower levels of medium terrace. The stratigraphy includes alluvial sands followed by black soil and capped by made ground.

2) Significant aeolization of sands from the terrace sediments (TD) allows concluding their deposition during the Vistulian (presumably the Late Vistulian).

3) During both the Meso- and the Neoholocene the Rudawa River flowed over this part of terrace.

4) Anthropogenic sediments (made ground) are dominated by quartz and macroscopically unidentified organic matter accompanied by mineral aggregates.

5) Three distinct horizons with slag fragments and increased amounts of charcoal point out to metallurgical activity. One such horizon is hosted in the soil whereas the remaining two occur in the made ground. The oldest horizon correlates with increased contents of $\mathrm{Zn}$ and $\mathrm{Cr}$ indicated by chemical analyses, which is typical of metallurgical operations of the Bronze Age. Thus, in the study area three periods of metal processing were present.

6) In the range of excavation the study area has not been build over with brick or stone buildings and might have been used for farming or storage.
7) The results demonstrate the scientific importance of further, similar projects run in poorly recognized parts of Kraków. Only such interdisciplinary and complementary studies will enable the determination of character and chronology of environmental and cultural changes.

8) The crucial problem is the standardization of sampling and research procedures, which would ensure compatibility of results and interpretations.

9) Palynological analyses revealed the significant changes of plant cover on and around the studied site. This very local data well documented the changes in strength and character of local human activity. Taxonomic composition of pollen spectra allowed to determine the probable time of its deposition which started from the Subboreal period and lasted with breaks at least till the Late Medieval period.

\section{ACKNOWLEDGMENTS}

This research has been partly supported by the Committee for Scientific Research (KBN) grants, allocated to Stanisław Staszic AGH University of Science and Technology (No. 11.11.140.882 and 11.11.140.560).

\section{REFERENCES}

Badura M, 1999. Szczatki gryki (Fagopyrum esculentum Moench) ze sredniowiecznego Kołobrzegu. (Remains of buckwheat (Fagopyrum esculentum Moench) from medieval Kołobrzeg). Polish Botanical Studies, Guidebook Series 23: 219-231.

Bieniek A, Wacnik A, Tomczyńska Z and Zaitz E, 2003. Badania paleobotaniczne średniowiecznego stanowiska archeologicznego Kraków ul. Kanonicza 17. (Palaeobotanical studies of medieval archaeological site from Kraków- 17 Kanonicza street). Unpublished Report. Władysław Szafer Institute of Botany in Kraków, Polish Academy of Sciences: 12 pp (in Polish).

Bieniek A, Wacnik A, and Tomczyńska Z, 2006. Rośliny z późnośredniowiecznych warstw archeologicznych na Rynku Głównym w Krakowie. Raport z badań przeprowadzonych w 2004 roku (Plants in late medieval archaeological layers in the Main Market Square in Cracow- a report from the research conducted in 2004). Materiaty Archeologiczne 36: 201-219 (in Polish).

Godłowska M, Kozłowski KK, Starkel L, and Wasylikowa K, 1987. Neolithic settlement at Pleszów and changes in the natural environment in the Vistula valley. Przeglad Archeologiczny 34: 133159 .

Good TR and Bryant ID, 1985. Fluvio-aeolian sedimentation - an example from Banks Island, N.W.T., Canada. Geografiska Annaler 67A: 33-46.

Goździk J, 2007. The Vistulian Aeolian succession in central Poland. Sedimentary Geology 193: 211-220.

Gworek B, Barański A, Czarnomski K, Sienkiewicz J and Porębska G, 2000. Procedura oceny ryzyka $w$ zarzadzaniu gruntami zanieczyszczonymi metalami ciężkimi (Risk evaluation procedure in management of grounds, contaminated with heavy metals). Warszawa, Instytut Ochrony Środowiska: 88 pp (in Polish).

Jamka R, 1963. Kraków w pradziejach (Cracow in primaval history). Biblioteka Archeologiczna 16: 5-317 (in Polish)

Karczewska A and Kabała C, 2005. Metodyka analiz laboratoryjnych gleb i roślin (Methodology of soil and plants laboratory analyses). Wrocław, Akademia Rolnicza: 28 pp (in Polish).

Kleczkowski AS and Adamczyk A, 1967. Mineral waters in Cracow and their connection with geological structure. Bulletin de l'Academie Polonaise des Sciences, Série des Sciences Géologiques et Géographigues 15(3): 171-178 (in Polish).

Kmietowicz-Drathowa I, 1975. Nowe dane o terasach Wisły i Rudawy w centrum Krakowa (New data about terraces of Vistula and Rudawa rivers in centre of Cracow). Sprawozdania z Posiedzeń 
Komisji Naukowych Polskiej Akademii Nauk, Oddziat w Krakowie 19(1): 396-397 (in Polish).

Krasnowolski B, 2003. Młynówka królewska - geneza i przekształcenia (The Młynówka Królewska Canal: origin and transformations). Rocznik Krakowski 69: 25-33 (in Polish).

Krumbein WC, 1941. Measurement and geological significance of shape and roundness of sedimentary particles. Journal Sedimentary Petrology 11: 64-72.

Laberschek J, 2005. Krakowski zespół osadniczy w wiekach XIII-XVI. Rozwój terytorialny (Cracovian settlement in 13th and 16th century. Territorial expansion). Rocznik Krakowski 71: 9-30 (in Polish).

Lamparski Z, 1992. Metody litologiczne (Lithologic methods). In: Lindner L, ed., Czwartorzęd. Osady, metody badań, stratygrafia. Warszawa, Wydawnictwo PAE: 276-293 (in Polish).

Latałowa M and Nalepka D, 1987. A study of the Late-Glacial and Holocene vegetation history of the Wolbrom area (SilesianCracovian Upland). Acta Palaeobotanica 27(1): 75-115.

Leszczyńska-Skrętowa Z, 1985a. Czarna Ulica (Black Street). Stownik historyczno-geograficzny województwa krakowskiego w średniowieczu 1(3): 438-439 (in Polish).

Leszczyńska-Skrętowa Z, 1985b. Czarna Wieś (Black Country). Stownik historyczno-geograficzny województwa krakowskiego $w$ średniowieczu 1(3): 439-441 (in Polish).

Lityńska-Zając M, 2001. Makroskopowe szczątki roślinne ze stan. $3 \mathrm{w}$ Kryspinowie i stan. 2 w Krakowie-Pychowicach (Macro-remains of plants from site 3 in Kryspinów and 2 in Kraków-Pychowice). In: Kadrow S, ed., Via Archaeologica, Zródła z badań wykopaliskowych na trasie autostrady A4 $w$ Matopolsce. Przyroda $i$ człowiek. Materiały do studiów. Kraków, Krakowski Zespół do Badań Autostrad: 93-130 (in Polish).

Lityńska-Zając M and Wasylikowa K, 2005. Przewodnik do badań archeobotanicznych (Guidebook to archaeobotanical studies). Poznań, Wydawnictwo Sorus: 110-113 (in Polish).

Madeyska E and Obidowicz A, 2001. Wyniki analiz paleobotanicznych stanowiska Cholerzyn (Palaeobotanical analyses of Cholerzyn site). In: Kadrow S, ed., Via Archaeologica, Zródła z badań wykopaliskowych na trasie autostrady A4 w Małopolsce. Przyroda i człowiek. Materiały do studiów. Kraków, Krakowski Zespół do Badań Autostrad: 63-74 (in Polish).

Mycielska-Dowgiałło E, 1998. Znaczenie interpretacyjne brył piaszczystych i żwirowych w osadach fluwialnych i fluwioglacjalnych (Interpretation value of sand and gravel blocks in fluvial and fluvioglacial deposits). In: Mycielska-Dowgiałło E, ed., Struktury sedymentacyjne $i$ postsedymentacyjne $w$ osadach czwartorzędowych $i$ ich wartość interpretacyj. Warszawa, Wydział Geografii i Studiów Regionalnych Uniwersytetu Warszawskiego: 115-118 (in Polish).

Mycielska-Dowgiałło E and Woronko B, 1998. Analiza obtoczenia i zmatowienia powierzchni ziarn kwarcowych frakcji piaszczystej i jej wartość interpretacyjna (Rounding and frosting analysis of quartz grains of sand fraction, and its interpretative value). Przeglad Geologiczny 46(12): 1275-1281.

Mycielska-Dowgiałło E and Woronko B, 2004. The degree of aeolization of Quaternary deposits in Poland as a tool for stratigraphic interpretation. Sedimentary Geology 168: 149-163, DOI 10.1016/j.sedgeo.2003.12.006.

Nalepka D, 1994. Historia roślinności w dolinie Wisły między Krakowem a ujściem Raby w późnym vistulianie I w holocenie (History of vegetation in the Vistula valley from Cracow to the mouth of the Raba river in the Late Vistulian and Holocene). In: Starkel L and Prokop P, eds., Przemiany środowiska przyrodniczego Karpat $i$ kotlin Podkarpackich. Warszawa, IGiPZ PAN, Warszawa Conference Papers 20: 19-32 (in Polish).

Nalepka D, 2003. Prehistoric and historic settlement recorded in a terrestrial pollen profile: Boreal to Subatlantic forest successin in a $60 \mathrm{~cm}$ thick sediment in Stanisławice (southern Poland). Acta Palaeobotanica 43(1): 101-112.

Pawlikowski M, 1992. Petroarcheologia (Petroarchaeology). Kraków, Akademia Górniczo-Hutnicza: 112 pp (in Polish).

Pieradzka K, 1931. Garbary przedmieście Krakowa (Garbary the suburb of Cracow). Bibljoteka Krakowska 71: 1-150 (in Polish)

Pisarczyk S, 2004. Grunty nasypowe, właściwości geotechniczne i metody ich badania (Fill soils, geotechnical properties and methods of their study). Warszawa, Oficyna Wydawnicza
Politechniki Warszawskiej: 238 pp (in Polish).

Radwański K, 1972. Stosunki wodne wczesnośredniowiecznego Okołu w Krakowie, ich wpływ na topografię osadnictwa, próby powiązania tych zjawisk ze zmianami klimatycznymi (Water regime of Early Medieval Okół in Cracow, their influence over topography of settlements, its connections of climatic changes). Materiaty Archeologiczne 13: 5-40 (in Polish).

Radwański K, 1975. Kraków przedlokacyjny - rozwój przestrzenny (Cracow before the grainting of the Foundation Charter). Polskie Towarzystwo Archeologiczne i Numizmatyczne, Oddział w Nowej Hucie, Muzeum Archeologiczne w Krakowie: 403 pp (in Polish).

Ralska-Jasiewiczowa M, Latałowa M, Wasylikowa K, Tobolski K, Madeyska E, Wright HE and Turner Ch, eds., 2004. Late Glacial and Holocene history of vegetation in Poland based on isopollen maps. Kraków, Władysław Szafer Institute of Botany, Polish Academy of Sciences: $444 \mathrm{pp}$.

Renfrew C and Bahn PG, 2000. Archeology: Theory, Methods and Practice. London, Thames and Hudson Ltd.: 600 pp.

Rutkowski J, 1987. Vistula river valley in the Cracow Gate during the Holocene. In: Starkel L, ed., Evolution of the Vistula river valley during the last 15000 year, part II, Polish Academy of Sciences, Institute of Geography and Spatial Organization, Geographical Studies, Special Issue 4: 31-50.

Rutkowski J and Sokołowski T, 1983. Wstęne badania petrograficzne czwartorzędowych żwirów rzecznych w regionie Krakowa (Preliminary petrographic study of Quaternary fluvial gravels of the Cracow region -southern Poland). Studia Geomorphologica Carpatho-Balcanica 16: 99-108 (in Polish).

Seppällä M, 2004. Wind as a geomorphic agent in cold climates. Cambridge, Cambridge University Press: 368 pp.

Setmajer J, 1973. Główne rysy budowy geologicznej oraz pierwotnej topografii Krakowa i strefy przełomowej Wisły (Main features of geological structure and primary topography of the Cracow area and the neighbouring Subcarpathian region). Acta Archaeologica Carpathica 13: 139-151.

Sokołowski T, Pazdur A, Wacnik A, Madeja J and Woronko B, 2006 Profil osadów stożka Prądnika w pobliżu Dworca PKP w Krakowie (Profile of Prądnik fan deposits near railway station in Cracow). Prace Komisji Paleogeografii Czwartorzędu Polskiej Akademii Umiejętności 4: 61-69 (in Polish).

Starkel L, 2001. Historia doliny Wisły od ostatniego zlodowacenia do dziś (Evolution of the Vistula river valley since the last glaciation till present). Polska Akademia Nauk, Instytut Geografii i Przestrzennego Zagospodarowania im. Stanisława Leszczyckiego, Monografie 2: 5-263 (in Polish).

Szczepanek K, 1971. Kras staszowski w świetle badań paleobotanicznych (The Staszów karst in the light of palaeobotanical studies South Poland). Acta Palaeobotanica 12(2): 102-112 (in Polish).

Traczewska-Białek Z, 1981. Opis inwentaryzacyjny z ilustracjami dawnych map wielkoskalowych Krakowa (Listing description with illustrations of old large-scale maps of Cracow). In: OdlanickiPoczobbutt M, ed., Catalogue of old large-scale maps of Cracow 16th-19th centuries. Warszawa-Kraków, Państwowe Wydawnictwo Naukowe: 29-269 (in Polish).

Wałowy A, 1986. Badania przy ulicy Krupniczej 26 w Krakowie (Studies in 26 Krupnicza street). Materiaty Archeologiczne 23: 93-110 (in Polish).

Wałowy A, 1990. Badania przy kościele i klasztorze oo. Karmelitów na Piasku w Krakowie w 1964 roku, wykop I (Studies next to Carmelite church and cloister, 1th archaeological excavation). Materiaty Archeologiczne 25: 49-64 (in Polish).

Wasylikowa K, 1978. Plant remains from Early and Late Medieval time found on the Wawel Hill in Cracow. Acta Palaeobotanica 19(2): 115-200.

Wieserowa A., 1979: Plant remains from the Early and Late Middle Ages found in the settlement layers of the Main Market Square in Cracow. Acta Palaeobotanica 20(2): 137-212.

Wiśniewski J, 1986. Garbary zw. też przed Bramą Szewską (Garbary also to go by the name in front of Szewska Gate). Stownik historyczno-geograficzny województwa krakowskiego $w$ średniowieczu 1(4): 693-706 (in Polish).

Zieliński T, 2007. The Pleistocene climate-controlled fluvial sedimentary record in the Bełchatów mine (central Poland). Sedimentary Geology 193: 203-209. 